\title{
Comparing two versions of a non-linear model for simulating leaf number and developmental stages in maize based on air temperature
}

\author{
Comparativo de duas versões de modelo não-linear para a simulação do número de folhas \\ e dos estágios de desenvolvimento do milho, baseado na temperatura do ar
}

\author{
Nereu Augusto Streck ${ }^{I}$ Luana Fernandes GabrielII Flavia Kaufmann Samboranha ${ }^{\text {II }}$ \\ Isabel Lago ${ }^{\text {III }}$ Ana Paula Schwantes ${ }^{\text {II }}$ Alfredo Schons ${ }^{\text {IV }}$
}

\section{ABSTRACT}

The Wang and Engel (WE) model simulates crop development considering the non-linear response of plant development to temperature. Daily air temperature is the input for the temperature response function $[f(T)]$ in the WE model, and because there are several approaches for computing daily temperatures, there are several ways to calculate the $f(T)$. The objective of this study was to compare two versions of the WE model for simulating leaf number and developmental stages in maize, considering two approaches for imputing daily air temperature (daily mean air temperature and daily minimum/ maximum air temperature). A two-year field experiment with the maize variety BRS Missões sown in several sowing dates was conducted in Santa Maria, Rio Grande do Sul State, Brazil, during the 2005-2006 and 2006-2007 growing seasons. The $f(T)$ in the WE model was calculated using daily mean air temperature calculated as the arithmetic average of daily minimum (TN) and maximum (TX) air temperatures (WE $\left.E_{\text {Tmean }}\right)$, and calculating an $f(T)$ using $T N$ and an $f(T)$ using $T X$ and then averaging the two $f(T) s\left(W E_{T m m}\right)$. Ligule and tip leaf number, and silking and physiological maturity developmental stages measured in the 2005-2006 growing season were used to estimate model coefficients and the ones measured in the 20062007 growing season were used as independent data sets to evaluate models. Predictions of ligule and tip leaf number, silking and physiological maturity of the maize variety BRS Missões were better with the $W E_{T m m}$ model than with the $W E_{\text {Tme }}$ model.

Key words: crop models, Zea mays, leaf number, phenology.

\section{RESUMO}

O modelo Wang e Engel (WE) simula o desenvolvimento das culturas considerando uma resposta nãolinear do desenvolvimento das plantas à temperatura. A temperatura diária do ar é o dado de entrada na função de resposta à temperatura $[f(T)]$ no modelo WE e, em função de haver várias maneiras de calcular a temperatura diária, há várias maneiras de calcular a $f(T)$. O objetivo deste estudo foi comparar duas versões do modelo WE para a simulação do número de folhas e dos estágios de desenvolvimento em milho, considerando dois métodos de entrada da temperatura diária do ar (temperatura média diária do ar e temperatura mínima/ máxima diária do ar). Um experimento de campo com a variedade de milho BRS Missões, semeado em várias datas de semeadura, foi conduzido em Santa Maria, Rio Grande do Sul, Brasil, durante os anos agrícolas 2005-2006 e 20062007. A $f(T)$ no modelo WE foi calculada usando-se a temperatura média diária do ar calculada pela média aritmética das temperaturas mínima (TN) e máxima (TX) diárias do ar $\left(W E_{\text {Tmean }}\right)$ e pela média de $f(T)$ usando $T N$ e pela de $f(T)$ usando $T X\left(W E_{T m}\right)$. O número de folhas expandidas e totais e os estágios de desenvolvimento (embonecamento e maturidade fisiológica) coletados no ano agrícola 2005-2006 foram usados para estimarem-se os coeficientes dos modelos; por sua vez, os estágios coletados no ano agrícola 2006-2007 foram usados como dados independentes para avaliar os modelos. A simulação do número de folhas expandidas e totais, do embonecamento e da maturidade fisiológica da variedade de milho BRS Missões foi melhor com o modelo $W E_{T m m}$ do que com o modelo $W E_{\text {Tme }}$

Palavras-chave: modelos agrícolas, Zea mays, número de folhas, fenologia.

'Departamento de Fitotecnia, Centro de Ciências Rurais (CCR), Universidade Federal de Santa Maria (UFSM), 97105-900, Santa

Maria, RS, Brasil. E-mail: nstreck2@yahoo.com.br. Autor para correspondência.

IICurso de Agronomia, CCR, UFSM, Santa Maria, RS, Brasil.

II'Programa de Pós-graduação em Engenharia Agrícola, CCR, UFSM, Santa Maria, RS, Brasil.

Iv Associação Rio-grandense de Empreendimentos de Assistência Técnica e Extensão Rural (ASCAR-EMATER/RS), Porto Alegre, RS, Brasil. 


\section{INTRODUCTION}

Plant growth and development are different but related processes. Plant growth refers to irreversible increase in the organ or in the whole plant physical dimension such as length, area, volume and weight, whereas plant development refers to processes related to cell differentiation, organ initiation (organogenesis), organ appearance (morphogenesis), and extends to crop senescence (HODGES, 1991; WILHELM \& McMASTER, 1995). Leaf appearance rate (LAR), leaf number (LN), date of developmental stages and duration of developmental phases are examples of development parameters of interest in many agronomic studies (AMIR \& SINCLAIR, 1991; MATTHEWS et al., 1994; BIRCH et al., 1998).

Temperature is a major environmental factor that drives LAR and development rate (r) in maize (HESKETH \& WARRINGTON, 1989; WHITE, 2001). Temperature effects on plant development are often assumed to be linear in the well-known thermal time approach, with units of ${ }^{\circ} \mathrm{C}$ day (GILMORE \& ROGERS, 1958; ARNOLD, 1960). A linear temperature response is often preferred because it is simple to implement, it has fewer coefficients, and it works well on many practical situations where air temperatures fall into the linear response of development to temperature range (XUE et al., 2004). However, the linear approach may fail under the situations that are not usual, such as in early and late sowings (when cool temperatures are more frequent), and under climate change scenarios (when high temperatures are much more frequent than under current climate). In these situations, response of biological processes, including plant development, to temperature falls into the non-linear response of development to temperature range (CUTFORTH \& SHAYKEWICH, 1990; YIN et al., 1995; STRECK et al., 2003a, b).

Plant development is simulated in the Wang and Engel (WE) model considering the non-linear effects of temperature on development (WANG \& ENGEL, 1998). The temperature response function [f(T)] in the WE model ranges from zero to one and is described by a beta function that has three coefficients with biological meaning, i.e the cardinal temperatures (minimum, optimum, and maximum) for development. Another feature of the WE model is that environmental factors and genetic factors are combined with the multiplicative approach. The multiplicative approach is more biologically sound to describe the interactions between plant development and environmental factors than other approaches such as the limiting factor and the additive approaches (STRECK et al., 2003a).
The WE model was first used to simulate development and LAR in winter wheat (WANG \& ENGEL, 1998; STRECK et al., 2003a; XUE et al., 2004). Further studies extended the applications of the WE model to simulate LAR and developmental stages to other crops such as muskmelon (STRECK et al., 2006), potato (STRECK et al., 2007a, b), eucalyptus seedlings (MARTINS \& STRECK, 2007), rice (STRECK et al., 2008a), maize (STRECK et al., 2008b), and soybean (SETIYONO et al., 2007). In these studies, predictions of LN and developmental stages were better with the WE model than with the thermal time approach.

When using the WE model, both LAR and development rate are calculated on a daily basis, i.e., at one day time step, and the input for the $\mathrm{f}(\mathrm{T})$ is daily air temperature (STRECK et al., 2003a, b; XUE et al., 2004). Daily air temperature records available at meteorological stations vary from minimum (TN) and maximum (TX) daily temperatures to hourly temperature values over $24 \mathrm{~h}$. Consequently, there are several ways to input temperature values for calculating the $\mathrm{f}(\mathrm{T})$ in the WE model, varying from using the daily mean temperature $\left(\mathrm{T}_{\text {mean }}\right)$ calculated as the average of TN and TX (STRECK et al., 2007a, b) or as the average of hourly values over 24h (STRECK et al., 2003a, b) to calculating the $\mathrm{f}(\mathrm{T})$ for each TN and TX or for each of the 24 hourly values and then average the $f(T)$ values (XUE et al., 2004). When using $\mathrm{T}_{\text {mean }}$ for calculating $\mathrm{f}(\mathrm{T}), \mathrm{T}_{\text {mean }}$ based on $24 \mathrm{~h}$ readings represent better the true $\mathrm{T}_{\text {mean }}$ than based on TN and TX (STRECK et al., 2003a, b; XUE et al., 2004). However, when using a non-linear temperature response function $[\mathrm{f}(\mathrm{T})]$, like the WE model, it is more appropriate to calculate the $\mathrm{f}(\mathrm{T})$ for each daily temperature values (24h temperature or TN and TX) and then average the $\mathrm{f}(\mathrm{T})$ values than average the daily temperatures first, then calculate $\mathrm{f}(\mathrm{T})$ (XUE et al., 2004).

In a two-year field experiment with winter wheat, the prediction of LN, represented by the Haun Stage, with the WE model was tested considering the $\mathrm{f}(\mathrm{T})$ calculated for TN and TX and then averaged, and considering the $\mathrm{f}(\mathrm{T})$ calculated from $\mathrm{T}_{\text {mean }}$ obtained by averaging hourly temperature values over $24 \mathrm{~h}$ (XUE et al., 2004). The results of this study were not consistent in the two growing seasons, with better predictions of LN in one growing season when the $\mathrm{f}(\mathrm{T})$ was calculated for TN and TX and then averaged, and better predictions of LN in the other growing season when the $\mathrm{f}(\mathrm{T})$ was calculated with $\mathrm{T}_{\text {mean }}$ averaged over $24 \mathrm{~h}$. In the study by XUE et al. (2004) the option of calculating $f(T)$ from $T_{\text {mean }}$ as the average of $T N$ and TX was not considered. STRECK et al. (2003a, b) used the $f(T)$ calculated from $T_{\text {mean }}$ obtained by averaging 
$24 \mathrm{~h}$ values for simulating development stages in winter wheat. More recently, the $f(T)$ of the WE model was calculated using $\mathrm{T}_{\text {mean }}$ calculated as the arithmetic average of TN and TX in muskmelon (STRECK et al., 2006), potato (STRECK et al., 2007a, b), eucalyptus seedlings (MARTINS \& STRECK, 2007), rice (STRECK et al., 2008a), and soybean (SETIYONO et al., 2007). Therefore, the comparison of the WE model using the $\mathrm{T}_{\text {mean }}$ as the average of TN and TX for calculating $\mathrm{f}(\mathrm{T})$ with the WE model using TN and TX first and then averaging $f(T)$ values has not been performed yet, which constituted the rationale for this study. Our hypothesis was that the predictions of $\mathrm{LN}$ and developmental stages in maize with the WE model are better when the $\mathrm{f}(\mathrm{T})$ is calculated for TN and TX and then averaged the two $f(T)$ values than when $f(T)$ is calculated from $\mathrm{T}_{\text {mean }}$. The underlying basis for this hypothesis is that, in the field, TN and TX fall much more often into the non-linear response of development to temperature range than the daily mean temperature.

The objective of this study was to compare two versions the WE model for simulating $\mathrm{LN}$ and developmental stages in maize considering two approaches for inputting daily air temperatures (daily mean temperature and daily minimum/maximum air temperatures).

\section{MATERIAL AND METHODS}

Data used in this study are from a two-year field experiment conducted at the Research Area, Plant Science Department, Federal University of Santa Maria, RS, Brazil (latitude: $29^{\circ} 43^{\prime} S$, longitude: 5342’W, altitude: 95m) during the 2005-2006 and 2006-2007 growing seasons. During the $2005 / 2006$ growing season, sowing dates (day/month/year) were 21/09/2005, 20/10/2005, 29/11/2005, 04/01/2006, 07/02/2006, 16/03/2006 and 12/ $04 / 2006$, and during the $2006 / 2007$ growing season, sowing dates were: 23/08/2006, 27/09/2006, 30/10/2006, 30/11/2006, 08/01/2007, 13/02/2007 and 15/03/2007. The maize variety BRS Missões, which is a recommended genotype for this location, was used in the experiment.

The experimental design was a randomized complete block with six replications. The experimental unit was a plot $2.4 \mathrm{~m}$ wide and $5.4 \mathrm{~m}$ long, with three rows in an E-W direction. Plant spacing was $0.8 \mathrm{~m}$ among rows and $0.21 \mathrm{~m}$ within rows, with a plant density of 6 plants $\mathrm{m}^{-2}$. The two outside rows were border rows.

Emergence (EM) date was the average date when $50 \%$ of the plants were emerged. One week after EM, three plants located in the center row in each plot were randomly selected and tagged with colored wires. These plants were used to count the number of fully expanded leaves (visible ligule=ligule LN) and the number of leaf tips (tip LN) once a week, and to record the date of silking (SI) and physiological maturity (PM) of the uppermost ear based on RITCHIE et al. (1997). Daily minimum (TN) and maximum (TX) air temperatures were measured by a standard meteorological station (Brazilian National Weather Service) located at about $200 \mathrm{~m}$ from the plots.

The WE model (WANG \& ENGEL, 1998) was used to simulate LAR and $r$ in maize. The general form of the WE model for LAR is: $L A R=L_{\text {max }} f(T)$, where LAR is the daily leaf appearance rate (leaves day $^{-1}$ ), $\mathrm{LAR}_{\max }$ is the maximum daily leaf appearance rate (leaves day ${ }^{-1}$ ), and $\mathrm{f}(\mathrm{T})$ is a dimensionless temperature response function (varying from zero to one), for LAR. The $f(T)$ is a beta function: $f(T)=\left[2\left(T-T_{\text {min }}\right)^{\alpha}\left(T_{\text {opt }}-T_{\text {min }}\right)^{\alpha}-\right.$ $\left.\left(\mathrm{T}-\mathrm{T}_{\text {min }}\right)^{2 \alpha}\right]\left(\mathrm{T}_{\text {opt }}-\mathrm{T}_{\text {min }}\right)^{-2 \alpha}$ for $\mathrm{T}_{\min } \leq \mathrm{T} \leq \mathrm{T}_{\text {max }}^{\text {min }}$ and $\mathrm{f}(\mathrm{T})=0$ for $\mathrm{T}<\mathrm{T}_{\min }$ or $\mathrm{T}>\mathrm{T}_{\max } ; \alpha=\ln (2)\left\{\ln \left[\left(\mathrm{T}_{\max }-\mathrm{T}_{\min }\right)\left(\mathrm{T}_{\mathrm{opt}}-\right.\right.\right.$ $\left.\left.\left.\mathrm{T}_{\min }\right)^{-1}\right]\right\}^{-1}$, where $\mathrm{T}_{\min }, \mathrm{T}_{\text {opt }}$, and $\mathrm{T}_{\max }$ are the cardinal (minimum, optimum, and maximum) temperatures for LAR and $\mathrm{T}$ is the air temperature. Based on the literature, the cardinal temperatures for LAR in maize were assumed $8^{\circ} \mathrm{C}, 31^{\circ} \mathrm{C}$, and $41^{\circ} \mathrm{C}$ (YAN \& HUNT, 1999; WHITE, 2001). The number of leaves (LN) was calculated by accumulating daily LAR values starting at $\mathrm{EM}$, i.e., $\mathrm{LN}=\Sigma \mathrm{LAR}$. LAR, LARmax and $\mathrm{LN}$ were expressed both on a ligule and tip leaf basis.

The developmental cycle of the maize crop was divided in two phases (RITCHIE et al., 1997): vegetative phase (from EM to SI) and reproductive phase (from SI to PM). The first step in the WE model is to calculate the daily rate of development (r). The developmental stage (DS) is calculated by accumulating the daily development rate values ( $\mathrm{DS}=\Sigma \mathrm{r}$ ). $\mathrm{DS}$ is zero at EM, one at SI, and two at PM. The general form of the WE model to simulate development in maize is: $r=r m a x, v f(T)$ for the vegetative phase (EM-SI), and $r=r m a x, r f(T)$ for the reproductive phase (SI-PM), where $r$ is the daily development rate $\left(\right.$ day $\left.^{-1}\right), r_{\text {max, }}$ and $r_{\text {max }, r}$ are the maximum daily development rate $\left(\right.$ day $\left.^{-1}\right)$ in the vegetative and reproductive phases, respectively, and $f(T)$ is a temperature response function, varying from zero to one The $\mathrm{f}(\mathrm{T})$ is the beta function, and the cardinal temperatures for development were assumed $\mathrm{T}_{\min }=8^{\circ} \mathrm{C}$, $\mathrm{T}_{\text {opt }}=28^{\circ} \mathrm{C}$, and $\mathrm{T}_{\max }=36^{\circ} \mathrm{C} \quad(\mathrm{CUTFORTH}$ \& SHAYKEWICH, 1990) for both the vegetative and the reproductive phases.

The $\mathrm{f}(\mathrm{T})$ in the WE model was calculated using two different approaches: using daily mean air temperature calculated as the arithmetic average of daily $\mathrm{TN}$ and TX ( $\mathrm{WE}_{\text {Tmean }}$ ), and calculating an $\mathrm{f}(\mathrm{T})$ using TN and an $\mathrm{f}(\mathrm{T})$ using TX and then averaged the two $\mathrm{f}(\mathrm{T}) \mathrm{s}\left(\mathrm{WE} \mathrm{Tmm}_{\mathrm{Tm}}\right)$.

Coefficients LAR ${ }_{\max }, r_{\max v}$, and $r_{\text {max } r}$ of the two versions of the WE model ( $\mathrm{WE}_{\text {Tmean }}$ and $\mathrm{WE}_{\mathrm{Tmm}}$ ) 
are genotype dependent. The coefficient $\mathrm{LAR}_{\max }$ was estimated using the least square method (XUE et al., 2004), and the coefficients $r_{\text {max } v}$ and $r_{\text {max } r}$ were estimated with the Marquardt method (STRECK et al., 2003a). For the coefficients estimation, ligule LN, tip LN, dates of EM, SI and PM, and daily air temperature data from the seven sowing dates during the 2005-2006 growing season were used.

The statistics used to evaluate models performance was the root mean square error (RMSE) (JANSSEN \& HEUBERGER, 1995), the index of agreement (d index) (WILLMOTT, 1981) and the accuracy of model 1 relative to the model 2 index $\left(\mathrm{E}_{12}\right.$ index)(ALLEN \& RAKTOE, 1981).

\section{RESULTS AND DISCUSSION}

The estimates of LAR were 0.421 leaves day $^{-1}$ and 0.452 leaves day ${ }^{-1}$ for ligule $L N$, and 0.584 leaves day ${ }^{-1}$ and 0.626 leaves day ${ }^{-1}$ for tip LN with the $\mathrm{WE}_{\text {Tmean }}$ model and with the $\mathrm{WE}_{\mathrm{Tmm}}$, respectively. These estimates indicate a $38 \%$ higher rate of tip leaf appearance than ligule leaf appearance. The consequence of this higher leaf appearance rate is the accumulation of the number of leaf tips at the whorl as plant develops until flag leaf tip appearance, from two leaf tips when the first ligule was visible to five-six leaf tips when ligule leaf number was 15 in this maize variety. Due to near freezing temperatures in June 2006, plants in the two latest sowing dates of the 2005-2006 growing season did not reach silking and therefore only five sowing dates were used to estimate the coefficients $r_{\max , v}$ and $r_{\text {max,r }}$. The estimates of $r_{\text {max }, v}$ and $r_{\text {max, }}$ were 0.0184 day $^{-1}$ and 0.0221 day $^{-1}$ with the $\mathrm{WE}_{\text {Tmean }}$ model, and 0.0254 day $^{-1}$ and 0.0289 day $^{-1}$ with the $\mathrm{WE}_{\mathrm{Tmm}}$ model, respectively. These results indicate that the estimates of maximum leaf appearance rates and maximum development rates, the genotype dependent coefficients of the WE model (eq. 1,6, and 7), are higher when the $f(T)$ is calculated using $T N$ and TX to calculate $f(T)$ than using $T_{\text {mean }}$ to calculate $f(T)$.

For the 2006-2007 growing season, near freezing temperatures in late April 2007 also led plants in the latest sowing date dying before SI and plants in the two latest sowing dates not completing PM. Observed and predicted ligule LN, tip LN, and DOY of SI and PM with the two versions of the WE model are presented in figure 1. Predictions were better with the $\mathrm{WE}_{\mathrm{Tmm}}$ model, with an overall RMSE (pooling all data) of 0.80 leaves for ligule LN, 1.29 for tip LN, and 3.8 days for the developmental stages SI and PM compared to the RMSE of 0.95 leaves for ligule LN, 1.54 for tip LN, and 12.1 days for SI and PM with the $\mathrm{WE}_{\text {Tmean }}$ model.
Among sowing dates, predictions of ligule LN were very good (RMSE less than 0.8 leaves) with both versions of the WE model in the first five sowing dates, and in five out of seven sowing dates the predictions of $\mathrm{LN}$ were the worst with the $\mathrm{WE}_{\text {Tmean }}$ model (Table 1). A considerable over prediction of the ligule LN was observed for the two latest sowing dates (13 Feb 2007 and 15 Mar 2007) with both models, with a slightly lower error with the $\mathrm{WE}_{\mathrm{Tmm}}$ model (Figure 1, Table 1). For tip LN, predictions were with a greater error (RMSE usually between one and two leaves), specially with the $\mathrm{WE}_{\text {Tmean }}$ model, with predictions being the best with the $\mathrm{WE}_{\mathrm{Tmm}}$ model in five out of seven sowing dates (Figure 1, Table 1). Similarly to ligule LN, over prediction of tip LN occurred for the two latest sowing dates for LN greater than five, with a smaller error with the $\mathrm{WE}_{\mathrm{Tmm}}$ model (Figure 1, Table 1). Other statistics followed similar trends for the predictions of ligule and tip LN. The d index was closer to one with the $\mathrm{WE}_{\mathrm{Tmm}}$ model and the $\mathrm{E}$ index was between zero and one in five out of seven sowing dates for both ligule and tip LN (Table 1).

Predictions of developmental stages were excellent with the $\mathrm{WE}_{\mathrm{Tmm}}$ model, with RMSE of only 2.7 days for SI and 4.3 days for PM compared to 4.3 days and 17.3 days with the $\mathrm{WE}_{\text {Tmean }}$ model (Figure 1, Table 2). Errors in the predictions (observed-predicted) of SI among sowing dates varied from +3 to -8 days with the $\mathrm{WE}_{\text {Tmean }}$ model and from 0 to +5 days with the $\mathrm{WE}_{\mathrm{Tmm}}$ model and predictions of PM had an error varying from +8 to -21 days and from 0 to -7 days with the $\mathrm{WE}_{\text {Tmean }}$ and $\mathrm{WE}_{\mathrm{Tmm}}$ models, respectively. The greatest improvement in the predictions with the $\mathrm{WE}_{\mathrm{Tmm}}$ model was for PM in the 23 Aug 2006 and 08 Jan 2007 sowing dates (Figure 1, Table 2), with an error of two and seven days with the $\mathrm{WE}_{\mathrm{Tmm}}$ model, and eight and 21 days with the $\mathrm{WE}_{\text {Tmean }}$ model, respectively. Other statistics also indicate better performance of the $\mathrm{WE}_{\mathrm{Tmm}}$ model for simulating SI and PM. The d index was 1.00 for SI with both models and 0.99 and 1.00 for $\mathrm{PM}$ with the $\mathrm{WE}_{\mathrm{Tmean}}$ and $\mathrm{WE}_{\mathrm{Tmm}}$ models, respectively, and the $\mathrm{E}_{12}$ index was lower than 1.00 for both SI and PM (Table 2).

Several methods to calculate the $\mathrm{f}(\mathrm{T})$ in the WE model for predicting LAR in winter wheat using air temperature were compared by XUE et al. (2004): $\mathrm{f}(\mathrm{T})$ calculated using mean temperature calculated from the average of 24 hourly values; $f(T)$ calculated for each 24 hourly values and daily $f(T)$ was then determined as the average hourly $\mathrm{f}(\mathrm{T})$; and $\mathrm{f}(\mathrm{T})$ calculated for minimum and maximum temperatures and then the resulting values of $f(T)$ were averaged. These authors concluded that using minimum and maximum 

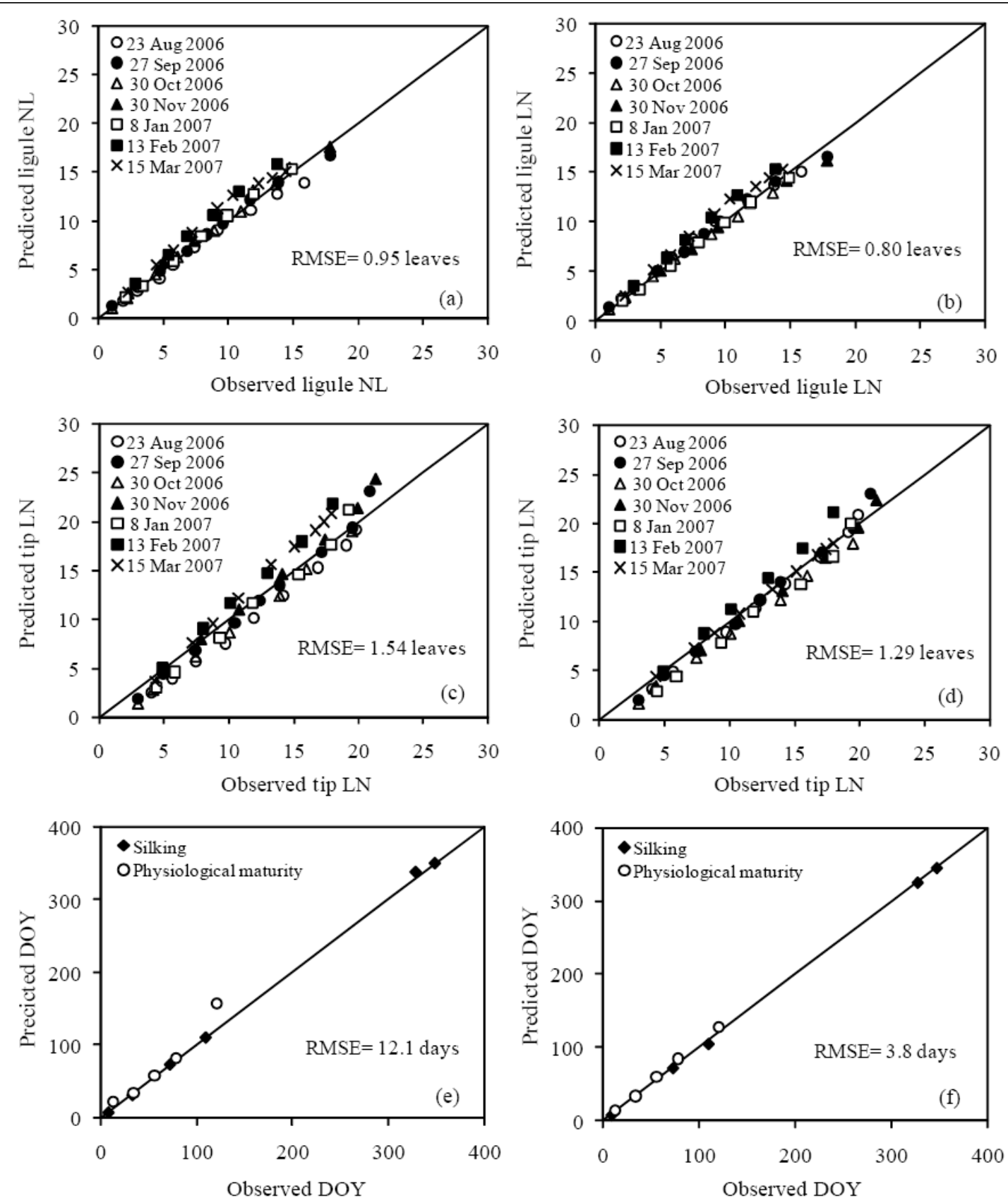

Figure 1 - Predicted versus observed ligule (a, b) and tip (c, d) leaf number (LN) and day of the year (DOY) of silking and physiological maturity $(\mathrm{e}, \mathrm{f})$ of the maize variety BRS Missões with the WE model using daily mean air temperature - $\mathrm{WE}_{\mathrm{Tmean}}(\mathrm{a}, \mathrm{c}, \mathrm{e})$ and using daily minimum and maximum air temperatures $-\mathrm{WE}_{\mathrm{Tmm}}(\mathrm{b}, \mathrm{d}, \mathrm{f})$ in the temperature response function. The solid line is the 1:1 line.

air temperatures was the least accurate method for predicting LAR. However, in one year of their study (1997- in table 2 of XUE et al., 2004), the RMSE was lower ( 0.55 leaves) with the $\mathrm{f}(\mathrm{T})$ based on minimum and maximum air temperature $\left(\mathrm{WE}_{\mathrm{Tmm}}\right)$ than the RMSE (0.58 leaves) with the $\mathrm{f}(\mathrm{T})$ based on daily mean temperature averaged over $24 \mathrm{~h}\left(\mathrm{WE}_{\text {Tmean }}\right)$.
In a non-linear model, averaging the TN and the TX daily temperatures first, and then calculate the $\mathrm{f}(\mathrm{T})$ with the mean daily temperature is not the best choice (XUE et al., 2004), because in the field, air temperature is often close to the cardinal temperatures (minimum, optimum, and maximum), where the response of development to temperature is non-linear. This 
Table 1 - Values of root mean square error (RMSE), $d$ index and $E_{12}$ index for the prediction of ligule leaf number (LN) and tip LN of the maize variety BRS Missões in several sowing dates during the 2006-2007 growing season with the WE model using daily mean air temperature $\left(\mathrm{WE}_{\mathrm{Tmean}}\right)$ and using daily minimum and maximum air temperature $\left(\mathrm{WE}_{\mathrm{Tmm}}\right)$ in the temperature response function. Santa Maria, RS, Brazil.

\begin{tabular}{|c|c|c|c|c|}
\hline \multirow{2}{*}{$\begin{array}{l}\text { Sowing date } \\
\text { (day/month/year) }\end{array}$} & \multicolumn{2}{|c|}{-----------------Ligule LN----------------- } & \multicolumn{2}{|c|}{------------------Tip LN---------------- } \\
\hline & $\mathrm{WE}_{\text {Tmean }}$ & $\mathrm{WE}_{\mathrm{Tmm}}$ & $\mathrm{WE}_{\mathrm{Tmean}}$ & $\mathrm{WE}_{\mathrm{Tmm}}$ \\
\hline & 081 & & 165 & 067 \\
\hline $\begin{array}{l}23 \text { Aug } 2006 \\
27 \text { Sep } 2006\end{array}$ & $\begin{array}{l}0.81 \\
0.47\end{array}$ & $\begin{array}{l}0.57 \\
0.59\end{array}$ & $\begin{array}{l}1.65 \\
0.96\end{array}$ & $\begin{array}{l}0.67 \\
0.85\end{array}$ \\
\hline 30 Oct 2006 & 0.12 & 0.35 & 1.23 & 1.43 \\
\hline 30 Nov 2006 & 0.80 & 0.67 & 1.39 & 0.87 \\
\hline 08 Jan 2006 & 0.47 & 0.23 & 1.16 & 1.36 \\
\hline 13 Feb 2006 & 1.63 & 1.31 & 2.11 & 1.67 \\
\hline 15 Mar 2006 & 1.42 & 1.23 & 1.96 & 1.85 \\
\hline 23 Aug 2006 & 0.99 & 1.00 & 0.98 & 1.00 \\
\hline 27 Sep 2006 & 1.00 & 1.00 & 0.99 & 1.00 \\
\hline 30 Oct 2006 & 1.00 & 1.00 & 0.99 & 0.98 \\
\hline 30 Nov 2006 & 0.99 & 1.00 & 0.99 & 0.99 \\
\hline 08 Jan 2007 & 1.00 & 1.00 & 0.99 & 0.99 \\
\hline 13 Feb 2007 & 0.96 & 0.97 & 0.96 & 0.97 \\
\hline 15 Mar 2007 & 0.97 & 0.98 & 0.96 & 0.97 \\
\hline 23 Aug 2006 & & & & \\
\hline 27 Sep 2006 & & & & \\
\hline 30 Oct 2006 & & & & \\
\hline 30 Nov 2006 & & & & \\
\hline 08 Jan 2007 & & & & \\
\hline 13 Feb 2007 & & & & \\
\hline 15 Mar 2007 & & & & \\
\hline
\end{tabular}

* $\mathrm{WE}_{\mathrm{Tmm}}$ was considered model 1 and the $\mathrm{WE}_{\mathrm{Tmean}}$ model was model 2.

hypothesis was confirmed in our study for maize as developmental events (LN and date of developmental stages) were better predicted with the $\mathrm{WE}_{\mathrm{Tmm}}$ model mainly in early (23 Aug 2006) and late (08 Jan 2007, 13

Table 2 - Values of root mean square error (RMSE, days), d index, and $\mathrm{E}_{12}$ index for the prediction of day of the year (DOY) of silking and physiological maturity of the maize variety BRS Missões in several sowing dates during the 2006-2007 growing season with the WE model using daily mean air temperature $\left(\mathrm{WE}_{\mathrm{Tmean}}\right)$ and using daily minimum and maximum air temperature $\left(\mathrm{WE}_{\mathrm{Tmm}}\right)$ in the temperature response function in different sowing dates (day/month/year). Santa Maria, RS, Brazil.

\begin{tabular}{lclll}
\hline \multirow{2}{*}{ Statistic } & \multicolumn{2}{c}{ Silking } & \multicolumn{2}{c}{ Physiological maturity } \\
& $\mathrm{WE}_{\text {Tmean }}$ & $\mathrm{WE}_{\mathrm{Tmm}}$ & $\mathrm{WE}_{\text {Tmean }}$ & $\mathrm{WE}_{\mathrm{Tmm}}$ \\
\hline RMSE & 4.3 & 2.7 & 17.3 & 4.8 \\
$\mathrm{~d}$ & 1.00 & 1.00 & 0.99 & 1.00 \\
$\mathrm{E}_{12}$ & - & 0.4054 & - & 0.0753 \\
\hline
\end{tabular}

Feb 2007 and 15 Mar 2007) sowing dates (Tables 1 and 2). At normal sowing dates, air temperatures often fall into the intermediate range between the minimum and the optimum temperatures where the temperature response to temperature is linear and in these situations both versions of the WE model worked well. Generality and robustness are important features of any simulation model and these features are given by how well the model performs under different environmental conditions. The fine tuning of the WE model for simulating LAR and developmental stages in maize by incorporating $\mathrm{TN}$ and $\mathrm{TX}$ increases the range of application (generality) of this model such as in studies with climate change scenarios, where both TN and TX are expected to increase (WEISS et al., 2003).

\section{CONCLUSIONS}

The calculation of the temperature response function in the WE model for predicting leaf number 
and developmental stages in maize is more appropriate when it is based on daily minimum and maximum air temperature than when it is based on daily mean air temperature, because of the reduction in RMSE. Predictions of developmental stages in maize were better for silking than for physiological maturity.

\section{ACKNOWLEDGEMENTS}

Authors thank Conselho Nacional de Desenvolvimento Científico e Tecnológico (CNPq), Coordenação de Aperfeiçoamento de Pessoal de Nível Superior (CAPES), and Fundação de Amparo à Pesquisa do Estado do Rio Grande do sul (FAPERGS) for financial support during this study.

\section{REFERENCES}

ALLEN, O.B.; RAKTOE, B.L. Accuracy analysis with special reference to the predictions of grassland yield. Biometry Journal, v. 23, p.371-388, 1981.

AMIR, J.; SINCLAIR, T.R. A model of the temperature and solar radiation effects on spring wheat growth and yield. Field Crops Research, v.28, p.47-58, 1991.

ARNOLD, C.Y. Maximum-minimum temperatures as a basis for computing heat units. Proceedings of the Americam Society for Horticultural Sciences, v.76, p.682-692, 1960.

BIRCH, C.J. et al. Modelling leaf production and crop development in maize (Zea mays L.) after tassel initiation under diverse conditions of temperature and photoperiod. Field Crops Research, v.58, p.81-95, 1998.

CUTFORTH, H.W.; SHAYKEWICH, C.F. A temperature response function for corn development. Agricultural and Forest Meteorology, v.50, p.159-171, 1990.

GILMORE, E.C.; ROGERS, J.S. Heat units as a method of measuring maturity in corn. Agronomy Journal, v.50, p.611615, 1958.

HESKETH J.D.; WARRINGTON, I.J. Corn growth response to temperature: rate and duration of leaf emergence. Agronomy Journal, v.81, p.696-701, 1989.

HODGES, T. Predicting crop phenology. Boston: CRC, 1991. 233p.

JANSSEN, P.H.M.; HEUBERGER, P.S.C. Calibration of process - oriented models. Ecological Modelling, v.83, p.55-56, 1995.

MARTINS, F.B.; STRECK, N.A. Aparecimento de folhas em mudas de eucalipto estimado por dois modelos. Pesquisa Agropecuária Brasileira, v.42, p.1091-1100, 2007.

MATTHEWS, R.B. et al. GUMCAS: a model describing the growth of cassava (Manihot esculenta L. Crantz). Field Crops Research, v.39, p.69-84, 1994.

RITCHIE, S.W. et al. How a corn plant develops. Ames: Cooperative Extension Service, 1997. 21p.
SETIYONO, T.D. et al. Understanding and modeling the effect of temperature and day length on soybean under high-yield conditions. Field crops research, v.100, p.257-271, 2007.

STRECK, N.A. et al. Improving predictions of developmental stages in winter wheat: A modified Wang and Engel model. Agricultural and Forest Meteorology, v.115, p.139-150, 2003a.

STRECK, N.A. et al. Incorporating a chronology response function into the prediction of leaf appearance rate in winter wheat. Annals of Botany, v.92, p.181-190, 2003b.

STRECK, N.A. et al. A non-linear model to simulate node appearance in muskmelon (Cucumis melo L.) grown inside plastic greenhouse as a function of air temperature. Revista Brasileira de Agrometeorologia, v.14, p.210-216, 2006.

STRECK, N.A. et al. Simulating the development of field grown potato (Solanum tuberosum L.). Agricultural and Forest Meteorology, v.142, p.1-11, 2007a.

STRECK, N.A. et al. Improving predictions of leaf appearance in field grown potato. Scientia Agricola, v.64, p.12-18, 2007b.

STRECK, N.A. et al. Simulating leaf appearance in rice. Agronomy Journal, v.100, p.490-501, 2008a.

STRECK, N.A. et al. Simulating maize phenology as a function of air temperature with a linear and a nonlinear model. Pesquisa Agropecuária Brasileira, v.43, p.449-455, 2008 b.

WANG, E.; ENGEL, T. Simulation of phenological development of wheat crops. Agricultural Systems, v.58, p.1-24, 1998.

WEISS, A. et al. Assessing winter wheat responses to climate change scenarios: a simulation study in the U.S. Great Plains. Climate Change, v.58, p.119-147, 2003.

WHITE, J.W. Modeling temperature response in wheat and maize. El Batán, Mexico: CIMMYT - International Maize and Wheat Improvement Center, 2001. 60p. (Series 03-01).

WILHELM, W.W.; Mc MASTER, G.S. Importance of the phyllochron in studying development and growth in grasses. Crop Science, v.35, n.1, p.1-3, 1995.

WILlmotT, C.J. On the validation of models. Physical Geography, v.2, p.184-194, 1981.

XUE, Q. et al. Predicting leaf appearance in field grown winter wheat: evaluating linear and non-linear models. Ecological Modelling, v.175, p.261-270, 2004.

YAN, W.; HUNT, L.A. An equation for modelling the temperature response of plants using only the cardinal temperatures. Annals of Botany, v.84, p.607-614, 1999.

YIN, X. et al. A nonlinear model for crop development as a function of temperature. Agricultural and Forest Meteorology, v.77, p.1-16, 1995. 